\title{
Interaction of native language interference and universal language interference on L2 intonation acquisition: Focusing on the pitch range variation*
}

\author{
Youngsook Yune* \\ College of Genaral Education, Kyungnam University, Changwon, Korea
}

\begin{abstract}
In this study, we examined the interactive aspects between pitch reduction phenomena considered a universal language phenomenon and native language interference in the production of L2 intonation performed by Chinese learners of Korean. To investigate their interaction, we conducted an acoustic analysis using acoustic measures such as pitch span, pitch level, pitch dynamic quotient, skewness, and kurtosis. In addition, the correlation between text comprehension and pitch was examined. The analyzed material consisted of four Korean discourses containing five and seven sentences of varying difficulty. Seven Korean native speakers and thirty Chinese learners who differed in their Korean proficiency participated in the production test. The results, for differences by language, showed that Chinese had a more expanded pitch span, and a higher pitch level than Korean. The analysis between groups showed that at the beginner and intermediate levels, pitch reduction was prominent, i.e., their Korean was characterized by a compressed pitch span, low pitch level, and less sentence internal pitch variation. Contrariwise, the pitch use of advanced speakers was most similar to Korean native speakers. There was no significant correlation between text difficulty and pitch use. Through this study, we observed that pitch reduction was more pronounced than native language interference in the phonetic layer.
\end{abstract}

Keywords: second language intonation, pitch span, pitch level, pitch range, pitch reduction, native language interference

1. 서론

언어는 특수성과 보편성을 지닌다. 이 두 특성은 음운, 의미, 통사 등 언어의 다양한 영역에서 나타난다. 본 연구는 제 2 언어 (L2)의 억양습득 과정에서 나타나는 언어 특수적 현상인 모국
어 간섭현상과 언어 보편적 현상인 음역(pitch range) 축소현상 이 어떤 양상으로 상호작용하는지 중국인 한국어 학습자들의 한국어 발화문을 통해 분석하고자 한다. 지금까지 L2의 억양습 득 과정에 가장 큰 영향을 미치는 요소는 모국어 억양체계의 전 이 또는 간섭으로 간주되었다. 각 언어는 고유한 억양체계를 가

\footnotetext{
* This work was supported by the Ministry of Education of the Republic of Korea and the National Research Foundation of Korea(NRF-2020S1A5A2A010 44515).

** ysy0622@kyungnam.ac.kr, Corresponding author Received 31 October 2021; Revised 6 December 2021; Accepted 6 December 2021

(c) Copyright 2021 Korean Society of Speech Sciences. This is an Open-Access article distributed under the terms of the Creative Commons Attribution NonCommercial License (http://creativecommons.org/licenses/by-nc/4.0) which permits unrestricted non-commercial use, distribution, and reproduction in any medium, provided the original work is properly cited.
} 
지며 각 언어의 억양체계가 지니는 음운론적 - 음성학적 속성 은 L2 억양 습득에 긍정적 또는 부정적 영향을 미친다는 것이 다. 그 결과 그동안 많은 연구들이 L2 학습자의 모국어와 목표 어 억양체계의 차이에 중점을 둔 대조분석을 통해 L2 억양의 오 류를 설명하였다(Bartkova et al., 2012; Busà, 2010; Grahanm \& Post, 2018; Hosseini, 2013; Jun \& Oh, 2000; Mennen, 2004, 2007; Ueyama, 1997).

그러나 비교적 최근에 이루어진 연구들은 L2 억양에서 발견 되는 오류가 L2 학습자들의 다양한 모국어 배경에 상관없이 유 사하게 나타난다고 보고하였다(Andreeva et al., 2014; Mennen et al., 2014; Ullakonoja, 2007; Zimmerer et al., 2014). 특히 음역 축 소 현상은 L2 억양에서 공통적으로 관찰되는 현상으로 지적되 었다. 즉 L2 억양은 학습자들의 모국어인 L1 억양이나 목표어 억양보다 축소된 음역과 음높이 변화(pitch variation)로 실현된 다는 것이다. 이러한 L2 억양의 음역 축소현상은 학습자 모국어 의 유형론적·언어학적 속성과 무관하게 거의 모든 L2 억양에서 관찰된다고 한다. 예를 들어 영어를 배우는 L2 화자들의 영어 발화문은 그들의 모국어에 상관없이 축소된 음역으로 실현되 며(Mennen et al., 2014), 핀란드인 학습자가 발화한 러시아어 (Ullakonoja, 2007)나 L2 프랑스어와 L2 독일어에서도 유사한 현 상이 관찰된다는 것이다(Zimmerer et al., 2014).

이는 L2 학습자들이 자신들의 모국어 음역이나 목표어 음역 과는 다른 음역으로 L2 억양을 산출함을 의미한다. 따라서 L2 억양의 음역 축소현상은 모국어 억양의 영향으로 유발되는 모 국어의 간섭과는 다른 성질로 L2 억양 전반에서 공통적으로 관 찰되는 언어 보편적 현상으로 규정될 수 있다. 이러한 사실은 Mennen et al.(2014)에서 지적된 것처럼 L2 억양체계를 습득하 는 과정에서 언어 보편적 억양패턴이 존재할 수 있다는 추론을 가능하게 한다. Zimmerer et al.(2014)은 L2 억양의 음역 축소현 상은 목표어 발화에 대한 L2 학습자의 확신 또는 자신감 부족으 로 유발되며 이러한 태도는 분절음이나 단어 발음에 더 집중하 게 함으로써 목표어 화자와 유사한 음역 실현을 억제하는 작용 을 한다고 한다. 또한 L2 억양의 축소된 음역은 의미의 정확성 이나 발화의 자연성에 부정적 영향을 미치며 외국인 악센트를 형성하는 요인이 되기도 한다(Andreeva et al., 2014).

그런데 L2 억양의 음역 축소현상과 모국어 간섭현상은 L2 억 양 습득과정에서 서로 배타적 또는 상충관계에 놓일 수 있다. 예를 들어 일반적으로 비성조언어에 비해 확대된 음역을 보이 는 성조언어(Yuan \& Liberman, 2014)를 모국어로 둔 학습자가 비성조언어를 목표어로 학습할 때 모국어 간섭에 의해 목표어 의 음역 확대가 나타날 수 있고 그와 동시에 보편적 현상인 음 역 축소의 영향도 받을 수 있다. 이 경우 두 요인이 어떤 양상으 로 서로 작용하여 L2 억양에 영향을 미치는가 하는 문제가 제기 된다. 즉 이 두 요인이 L2 억양 습득과정의 어떤 단계에서 어떤 순서(순차적 또는 동시적)와 양상으로 일어나는지에 대한 이해 가 필요하다.

만약이 두 층위의 간섭현상에 대한 이해가 부족하다면 L2 억 양에서 관찰되는 다양한 오류가 모국어 간섭으로만 귀속되어
L2 억양의 본질을 제대로 파악할 수 없고 그에 상응하는 교수학습 방법도 강구될 수 없다. 하지만 지금까지의 선행연구에서 는 모국어 간섭현상과 음역 축소현상이 독립적으로 분석되었 기에 두 현상의 상호작용 양상은 제대로 밝혀지지 못하였다.

이에 본 연구에서는 모국어 간섭현상과 음역 축소현상의 충 돌을 가장 잘 관찰할 수 있을 것으로 판단되는 성조언어 중 하 나인 중국어 모국어 화자를 대상으로 두 요인의 상호작용 양상 을 살펴보고자 한다. 즉 한국어를 학습하는 중국인 학습자들의 한국어 억양 습득과정에서 언어 특수적 간섭과 언어 보편적 간 섭현상이 어떤 순서와 양상으로 상호작용하는지 관찰하고 이 를 통해 L2 억양의 본질 탐색을 모색해 보고자 한다.

\section{2. 한국어와 중국어 억양체계}

한국어와 중국어는 운율 유형론적으로 상이한 언어군에 속 한다. 한국어 표준어의 근간이 되는 서울말은 성조가 단어의 의 미 변별에 관여하지 않는 비성조언어인 반면 중국어는 각 음절 이 고유한 성조를 지니며 성조는 단어의 의미 변별에 직접 관여 하는 음운론적 기능을 하는 성조 언어이다. 따라서 한국어와 중 국어는 음높이 곡선의 언어학적 사용과 해석이 다르다.

한국어의 문장 억양은 하나 이상의 음절이 모여 형성되는 강 세구의 피치패턴과 하나 이상의 강세구가 모여 형성되는 억양 구의 경계성조에 의해 이루어진다(Jun, 2000). 반면 중국어는 각 음절이 그 형태와 높이가 다른 네 개의 성조로 구별되며, 성조 는 구절이나 문장 층위의 음높이와 관련된 억양과 공존하면서 상호 영향을 준다고 한다(Jung, 2014). 이처럼 중국어의 문장 억 양은 음절이 지니는 고유한 성조와 문장 억양의 상호작용으로 형성되는데 성조 본래의 특징을 유지하면서도 문장 억양 실현 이 가능하며 각 성조는 실제 연결과정에서 음운론적 음높이의 변화(tone sandhi)를 겪기도 한다(Lee \& Sohn, 2010). 상기한 바 와 같이 일반적으로 성조언어는 비성조언어보다 확대된 피치 대역으로 실현된다고 한다(Yuan \& Liberman, 2014).

따라서 모국어 간섭현상의 측면에서 보면 중국인학습자들의 한국어 발화문은 모국어의 영향으로 한국어화자보다 확대된 음역을 사용할 가능성을 예측할 수 있다. 또한 이런 양상은 중 국인 한국어학습자들의 음운론적 - 음성학적 억양오류에서 부 분적으로 관찰되는 현상이기도 한다(Kim \& Baek, 2016; Park, 2009; Park, 2012). 그러나 상기한 바와 같이 L2 억양에서의 음역 축소현상은 학습자의 모국어와 상관없이 언어 보편적으로 나 타나는 현상인 만큼 이 두 요인이 어떤 양상으로 상호작용하는 지 중국인 한국어학습자들을 통해 살펴보고자 한다.

\section{3. 연구 방법}

\section{1. 실험 자료}

본 연구의 분석자료는 네 개의 짧은 담화이다. 선행연구 (Zimmerer et al., 2014)에 의하면 모국어 유형이나 목표어 숙달 도 외 발화문의 유형 또한 음역에 영향을 미치며 문장 낭독보다 
이야기 낭독에서 음역의 변화가 심하다고 한다. 따라서 담화에 서 음역의 변화양상을 더 효율적으로 관찰할 수 있을 것이다.

분석자료로 사용된 네 개의 짧은 담화는 5 문장으로 된 2 개의 담화와 7문장으로 된 2개의 담화이다. 담화의 난이도는 초·중. 고급 수준으로, 난이도는 자료의 출처(초급 또는 중급 자료집) 와 담화 전체 내용의 이해 용이도와 관련이 있다. 1 개의 초급 담 화는 연구에 참여하는 모든 중국인 학습자가, 2 개의 중급 담화 는 중급수준 이상의 학습자가, 그리고 1 개의 고급 담화는 고급 이상의 학습자가 전체 내용을 이해할 수 있을 것으로 판단되는 자료로 구성하였다. 그리고 분석자료의 난이도 차이를 통해 의 미인지 여부와 음높이 변화와의 관련성도 살펴보고자 한다. Zimmerer et al.(2014)에 의하면 L2 억양의 음역 축소현상은 목 표어 발화에 대한 L2 학습자의 확신 또는 자신감 부족으로 유발 된다고 한다. 이는 문장의 의미 인지 여부가 L2 발화의 자신감 에 영향을 줄 수 있음을 의미한다. 문장의 의미를 모른다는 것 은 문장을 이루는 연속된 단어들의 의미 관계나 단어들의 연결 로 구축되는 상위의 의미를 파악하지 못하는 것을 나타내므로 이 경우 개별 단어의 발화에 집중하게 될 것이기 때문이다. 따 라서 문장이나 담화의 의미 인지 여부와 음역과의 관련성이 발 견된다면 음역 축소현상은 상당 부분 의미 파악 여부에 의해 설 명될 수 있을 것이다. 분석자료는 부록에 제시되었다.

분석자료(1)은 5 문장으로 된 초급 수준 담화로 한국어능력시 험 초급 읽기 문제를 발음하기 쉽도록 어려운 받침 단어를 일부 교체하여 구성하였다. 5 문장과 7 문장으로 된 2 개의 중급 담화 (2)와 (3)은 한국어능력시험 중급 연습 문제집의 읽기 문제와 중 급 한국어 교재의 읽기 자료를 부분적으로 수정하여 구성하였 고 7문장으로 된 고급 자료 (4)는 인터넷 자료를 편집한 것이다. 이 중 고급 자료는 개별 단어의 의미를 아는 것만으로는 문장과 담화 전체의 의미를 정확히 파악할 수 없다는 점에서 초· 중급 자료와 구별된다. 4 개의 담화는 모두 단문과 복문이 섞여 있다.

한국어로 된 4 개의 분석자료는 한국어와 중국어의 음역 비교 를 위해 어순과 통사구조, 문장 수와 길이를 최대한 유지하면서 중국어로 번역하였다. 그 결과 4개의 담화를 구성하는 총 문장 수는 한국어 24 문장, 중국어 24 문장으로 동일하다.

\section{2. 피험자}

본 연구의 발화실험에는 한국어 화자 7 명과 초 - 중 · 고급 수 준의 한국어 숙달도를 가진 중국인 한국어학습자 각 10 명 총 37 명이 참여하였다. 7명의 한국어 화자(남 4명, 여 3명)는 대조군 집단으로 경기 및 서울지역에서 태어나거나 자란 표준한국어 구사자들이다. 이들 중 3 명은 경상지역에서 출생하여 어린 시 절 경기지역으로 이주하였는데 2 명은 5 살 이전에, 1 명은 10 살 경에 경기지역으로 이주하였다. 이들 3 명은 사전 인터뷰 과정 에서 출생지와 성장지를 조사하기 전까지 지방 출신임을 전혀 알아차리지 못할 정도로 경기지역 화자들과 동일한 표준발음 과 억양을 구사하였다. 따라서 7명의 한국화자들은 억양이나 발음에서 개인적 특이성을 보이지 않고 한국어 표준어 분절음 과 억양의 전형성을 보여주는 화자들로 특정 지을 수 있다. 한
국인화자는 모두 대학생이며 평균 연령은 만 21.3세이다.

중국인 한국어학습자들은 표준 중국어인 보통어를 사용하고 한국어를 읽고 말하는 데 특별한 문제가 없는 화자들로 선정하 였다. 10 명(남 5명, 여 5명)의 초급화자는 한국어능력시험 1-2 급 합격자나 그에 준하는 한국어 실력을 가진 학습자로 한국어 학습 기간 6 개월 이상 1.6 년 미만으로 한정하였다. 이들 중 7명 은 한국 체류 경험이 없이 중국대학에서 한국어를 학습하는 학 생들이며 나머지 3 명은 한국대학에 재학 중인 학생들이다. 중 급화자 10 명(남 5명, 여 5명)은 한국어능력시험 3-4급 합격자 나 그에 준하는 한국어실력을 가진 화자들로 한국어 학습기간 1.6년 이상 2.6년 미만의 학습자들이다. 마지막으로 고급화자 10 명(남 5명, 여 5명)은 한국어능력시험 5-6급에 합격하였거나 그에 준하는 한국어실력을 지니며 한국어학습기간 2.6년 이상 의 학습자들이다. 중 - 고급 학습자들도 한국의 대학 또는 대학 원에서 한국어를 전공하거나 한국어를 교양으로 학습한 학생 들이다. 초급 학습자들의 평균 연령은 22.2세이고 중급과 고급 학습자들은 각각 22.4 세, 25세이다.

\section{3. 녹음}

녹음은 한국과 중국에서 실시되었다. 한국인화자 7명과 초급 중국인 학습자 3 명, 그리고 중 · 고급 중국인 학습자 20 명의 녹 음은 연구자에 의해 한국에서 실시되었고 초급화자 중 7 명의 녹음은 중국 현지에서 연구보조원에 의해 진행되었다. 한국어 모국어 화자 7 명은 한국어 자료 녹음에만 참여하였고, 중국인 학습자 30 명은 한국어 자료와 중국어 자료 녹음에 참여하였다. 한국에서의 녹음은 Sony사의 PCM M10과 내장마이크를, 중국에 서는 Sony사의 PCM A10 녹음기 및 내장 마이크를 사용하였다.

한국과 중국에서의 녹음은 동일한 절차와 방법으로 진행되 었다. 녹음은 모두 조용한 방에서 실시하였고 $44,100 \mathrm{kHz}, 16 \mathrm{bit}$ 모드로 녹음되었다. 녹음 전 연구 목적을 설명하고 연습할 수 있는 충분한 시간을 부여하였다. 중국인학습자들의 녹음은 한 국어, 중국어 순으로 하였으며 한국어 녹음이 완전히 완료된 후 중국어 자료를 제공하였다. 그리고 한국어 자료 제공 시 문장의 의미나 억양, 발음에 대한 정보는 전혀 제공하지 않았다. 37 명 의 피험자들은 각 단락을 보통 속도로 5 회를 기본으로 반복 발 화하였고 발화가 잘못된 경우 5 회를 초과하여 발화하였다.

피험자들의 발화문 중 담화 중간에 문장을 수정 발화하지 않 은 자료를 우선적으로 선별하였고 그 중 각 담화별로 가장 자연 스럽고 억양 곡선이 잘 드러나는 1 회분의 자료를 선별하여 분 석하였다. 한국어 분석자료는 총 888 문장으로 이는 37 명의 화 자가 4 개의 담화 총 24 문장을 발화한 것이며, 중국어 분석자료 는 총 720 문장으로 이는 30 명의 중국인 화자가 4 개의 담화 24 문 장을 발화한 수이다. 따라서 총 분석 문장은 1,608 문장이다.

\section{4. 연구 가설 및 분석 절차}

본 연구는 언어 보편적 현상인 음역 축소현상과 모국어 간섭 현상의 상호 작용을 분석하고자 다음과 같은 가설에서 출발하 였다. 우선 (1)음역 축소가 모국어 간섭 전에 일어난다면 초급 
학습자들의 음역이 가장 좁게 나타날 것이다. (2) 음역 축소가 모국어 간섭 후에 나타난다면 초급의 음역이 가장 확대되어 나 타날 것이다. (3) 고급 단계는 음역 축소와 모국어간섭이 완화되 어 목표어 음역에 가장 근접할 것이다. (4) 상기한 (1)-(3)의 가 설을 바탕으로 한다면 중급은 음역 축소나 모국어간섭 중 하나 가 가장 활발히 나타날 수 있다. (5) 만약 (1)과 (2)의 가설이 성립 하지 않는다면 두 요인이 동시에 발생할 수 있다.

이를 위해 본 연구에서는 ‘언어 간 분석', ‘집단 간 분석, 집단 내 분석'을 실시하였다. 언어 간 분석은 $\mathrm{L} 1$ 으로서의 한국어와 중국어의 음역을 조사하는 것으로 두 언어의 음역 차이를 비교. 분석하는 것이다. 이를 통해 중국인 한국어 학습자들의 한국어 억양습득 과정에서 나타날 수 있는 모국어인 중국어 음역의 잠 재적 영향의 범위를 파악하고자 한다. ‘집단 간 분석'은 한국어 발화문에서 나타나는 한국어 모국어집단과 초 - 중 · 고급 중국 인 한국어학습자 간 음역의 차이를 관찰하는 것으로 한국어 숙 달도와 관련된 음역 변화의 관찰을 목적으로 한다. '집단 내 분 석'은 중국인 학습자들이 발화한 중국어(L1)와 한국어(L2) 간 음역을 비교 - 분석하여 피치 축소와 모국어 간섭이 나타나는 양상을 살펴보고자 하였다.

이 세 유형의 분석은 두 요인이 중국인학습자들의 한국어 억 양습득 과정의 어떤 단계에서 어떤 순서로 나타나는지 파악하 게 할 것이다. 이와 더불어 음역 변화와 담화의 의미 인지 여부 와의 관련성도 살펴볼 것이다.

\section{5. 음성학적 분석}

음성학적 분석은 음성분석 프로그램 Praat을 사용하여 Pitch $\operatorname{span}($ 음역 변동범위)과 Pitch level(발화문의 평균 음높이), Pitch dynamic quotient(PDQ) 그리고 왜도(skewness)와 첨도(kurtosis) 값을 통해 살펴볼 것이다.

Pitch span과 Pitch level은 Ladd(1996)에 의해 소개된 이후 언 어 간 또는 언어 내 음역의 변화와 차이 분석에 사용되고 있다. Pitch span은 음높이 곡선의 변동 폭을 나타내는 것으로 발화문 의 F0 최댓값과 최솟값의 차이로 측정된다. Pitch level은 음높이 곡선의 전반적 높이를 나타내며 각 문장의 평균 F0 값과 화자의 최저 F0 값과의 차이를 바탕으로 산출된다. 본 연구에서 Pitch span은 단락 내 각 문장의 F0 최댓값과 해당 단락 최솟값과의 차 이를, Pitch level은 단락 내 각 문장의 평균 F0 값과 해당 단락 최 솟값과의 차이를 측정한 후 이 값 $(\mathrm{Hz})$ 을 $1 / 4$ tone $(\mathrm{Qt})$ 으로 정량 화하여 산출하였다. Pitch span과 Pitch level은 언어 간 음역의 차 이를 잘 드러내는데 게르만어족은 슬라브어족보다 좁은 $\operatorname{span}$ 과 낮은 level로 특징지어진다고 한다(Andreeva et al., 2014).

$\mathrm{PDQ}$ 는 Zimmerer et al.(2014)에서 사용된 방법으로 각 문장의 F0 값을 일정 간격(Zimmerer et al., 2014는 매 $10 \mathrm{~ms}$ )으로 측정하 여 평균을 구한 후 그 표준편차를 평균값으로 나누어 구한다. $\mathrm{PDQ}$ 로 각 문장의 음높이 곡선의 변화량을 살필 수 있으며 그 값이 낮을수록 음높이 변화가 작다고 한다. 왜도와 첨도는 분석 자료의 정규 분포성을 진단하는 수치로 왜도 값을 통해 자료의 분포가 좌우대칭인 정규분포에 비해 오른쪽 또는 왼쪽 중 어느
쪽에 편중되었는가를 알 수 있다. 분포가 왼쪽에 편중된 경우 왜도 값은 양의 값을 가지며, 오른쪽에 편중된 경우 음의 값을 가진다. 첨도는 분포의 정점이 정규분포에 비해 얼마나 뾰족한 지 또는 완만한지를 나타낸다. 왜도와 첨도 값이 0 에 가까울수 록 정규분포에 가깝다. 이 수치를 통해 언어 간 또는 집단 간 음 역의 분포 양상을 비교할 수 있다.

따라서 Pitch span과 Pitch level을 통해 단락 내 음역의 변동 폭을 분석하고, $\mathrm{PDQ}$ 를 통해 각 문장의 음역 변동범위를 측정하 며, 왜도와 첨도 값을 통해 음높이 값의 분포 범위를 측정하여 언어 간·집단 간 음역의 변동양상을 비교하고자 한다. 이상의 분석을 통해 얻어진 결과는 $t$-test와 ANOVA를 통해 통계적 유 의미성을 살펴볼 것이다.

\section{4. 결과}

\subsection{Pitch Span \& Pitch Level}

\subsection{1. 언어 간 분석}

Pitch span과 Pitch level을 통해 우선 한국화자가 발화한 한국 어와 중국화자가 발화한 중국어의 언어 간 음역을 비교하였다. 결과는 그림 1 과 그림 2에 제시되었다. 그림 1은 한국어와 중국 어의 Pitch span 값의 평균과 분포를, 그림 2는 Pitch level 값의 평 균과 분포를 나타낸다.

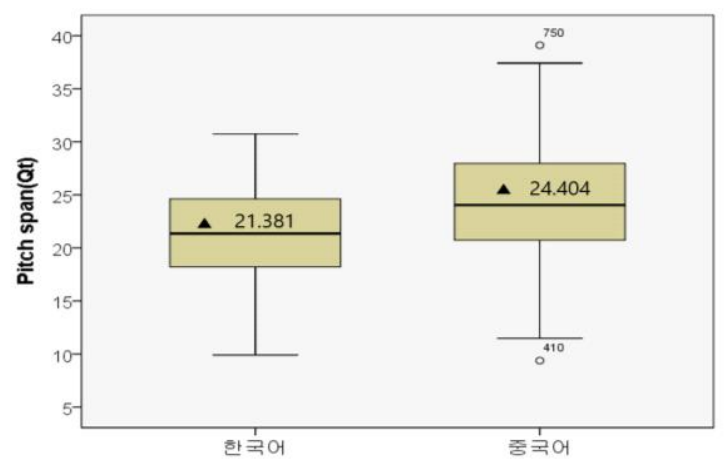

그림 1. 한국어와 중국어의 Pitch $\operatorname{span}(\mathbf{\Lambda}$ 평균값)

Figure 1. Pitch span of Korean and Chinese sentences $(\boldsymbol{\Lambda}$ mean value $)$

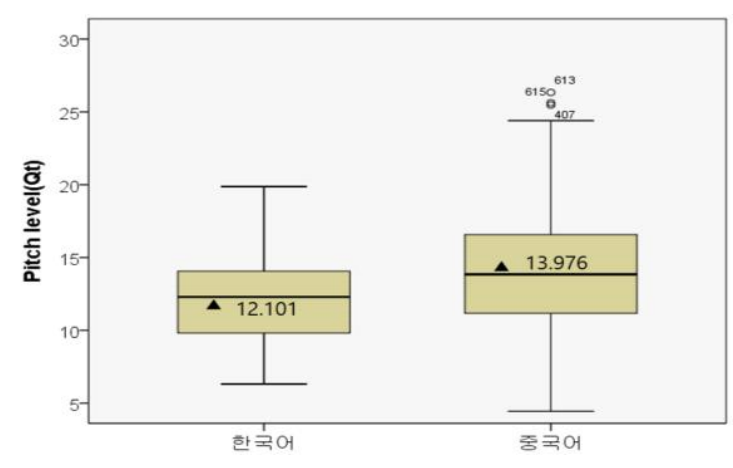

그림 2. 한국어와 중국어의 Pitch level( $\boldsymbol{\Delta}$ 평균값)

Figure 2. Pitch level of Korean and Chinese sentences $(\boldsymbol{\Lambda}$ mean value $)$ 
그림 1 과 2 를 통해 우선 한국어는 중국어보다 축소된 Pitch span과 낮은 Pitch level로 실현됨을 알 수 있다. Pitch span의 경우 한국어는 $9.90 \mathrm{Qt}-30.75 \mathrm{Qt}$ 의 분포를 보이며 평균값은 $21.38 \mathrm{Qt}$ 이 다. 반면 중국어는 $9.38 \mathrm{Qt}-39.10 \mathrm{Qt}$ 에 걸쳐 분포하며 평균 Pitch $\operatorname{span}$ 은 $24.40 \mathrm{Qt}$ 이다. 중국어는 한국어보다 $9 \mathrm{Qt}$ 이상 확대된 음 역을 보이며 평균 $3 \mathrm{Qt}$ 높은 대역에서 산출된다. Pitch level의 경 우 한국어는 $6.31 \mathrm{Qt}-19.87 \mathrm{Qt}$ 의 분포를 보이며 평균은 $12.10 \mathrm{Qt}$ 이다. 중국어는 $4.44 \mathrm{Qt}-26.33 \mathrm{Qt}$ 에 걸쳐 분포하며 평균은 13.98(3.82)Qt이다. 이는 중국어 문장의 평균 음높이가 한국어보 다 약 1.8 배 확대된 음역대에 걸쳐 실현됨을 의미하며 문장의 평균 음높이 또한 $1.8 \mathrm{Qt}$ 높다. 따라서 Pitch span과 Pitch level 값 을 통해 중국어는 한국어보다 넓은 음역대에 걸쳐 산출되며 단 락 내 각 문장도 한국어보다 높은 음역대에 위치함을 알 수 있 다. 본 연구의 자료만을 근거로 정의한다면 중국어는 한국어보 다 높은 Pitch span과 Pitch level로 특징지어진다고 할 수 있다.

두 언어에서 나타나는 Pitch span과 Pitch level 값이 통계적으 로 유의미한 차이가 있는지 살펴보고자 독립표본 $t$-검정을 실시 했다. 결과는 표 1 에 제시되었다. $t$-검정 결과 두 집단은 Pitch $\operatorname{span}(t=-7.605, d f=278.590, p<.000)$ 과 $\operatorname{Pitch} \operatorname{level}(t=-7.192$, $d f=324.925, p<.000)$ 모두에서 유의미한 차이를 보인다.

표 1. Pitch span과 Pitch level의 독립표본 $t$-검정 Table1. Results of $t$-test on Pitch span and Pitch level

\begin{tabular}{|c|c|c|c|c|c|}
\hline & & $\mathrm{N}$ & Mean(SD) & $t$-value & $p$-value \\
\hline \multirow{2}{*}{$\begin{array}{l}\text { Pitch } \\
\text { span }\end{array}$} & $\mathrm{KS}$ & 168 & $21.38(4.51)$ & \multirow{2}{*}{-7.605} & \multirow{2}{*}{.000} \\
\hline & $\mathrm{CS}$ & 720 & $24.40(5.16)$ & & \\
\hline \multirow{2}{*}{$\begin{array}{l}\text { Pitch } \\
\text { level }\end{array}$} & $\mathrm{KS}$ & 168 & $12.10(2.83)$ & \multirow{2}{*}{-7.192} & \multirow{2}{*}{.000} \\
\hline & $\mathrm{CS}$ & 720 & $13.98(3.82)$ & & \\
\hline
\end{tabular}

\subsection{2. 집단 간 분석}

Pitch span과 Pitch level에서 나타난 한국어와 중국어의 특징 을 바탕으로 중국인 학습자들의 한국어 발화문에서 음역 축소 와 모국어 간섭현상이 어떤 양상으로 나타나는지 살펴보고자 한국화자와 초 - 중 - 고급 중국화자를 대상으로 집단 간 분석 을 실시했다. 집단 간 분석은 한국화자와 초 - 중 - 고급 학습자 가 발화한 한국어 문장의 Pitch span과 Pitch level 값의 비교·분 석을 통해 이루어졌다. 결과는 그림 3과 4에 제시되었다. 그림 3 과 4에서 $\mathrm{KS}$ 는 한국인 화자를 나타내며, $\mathrm{CS} 1, \mathrm{CS} 2, \mathrm{CS} 3$ 는 각각 초·중·고급 중국인 한국어학습자를 나타낸다. 그리고 마지막 $\mathrm{CS}$ 는 중국인화자들이 발화한 중국어 문장의 Pitch $\operatorname{span}($ 그림 3) 과 Pitch level(그림 4)로 중국인 학습자들의 한국어 발화문과 모 국어 발화문을 비교하고자 제시하였다.

우선 그림 3의 Pitch span 값을 살펴보면 한국어 문장에서 나타 난 $\mathrm{CS} 1$ 과 $\mathrm{CS} 2, \mathrm{CS} 3$ 의 평균 Pitch span은 각각 $17.25 \mathrm{Qt}, 18.38 \mathrm{Qt}$, 21.62Qt으로 숙달도가 낮은 $\mathrm{CS} 1$ 과 $\mathrm{CS} 2$ 는 축소된 Pitch span을 보인다. CS1과 $\mathrm{CS} 2$ 의 평균 Pitch span은 한국어의 평균 Pitch $\operatorname{span}$ 인 21.38Qt이나 중국어의 평균인 $24.40 \mathrm{Qt}$ 에 훨씬 못 미치고 있다. CS3은 한국화자의 평균 Pitch span보다 미세하게 높으나 모국어인 중국어보다 한국어의 평균 Pitch span에 훨씬 근접해
있다. Pitch span의 분포양상은 $\mathrm{CS} 1$ 의 경우 $9.98 \mathrm{Qt}-26.63 \mathrm{Qt}$, $\mathrm{CS} 2$ 는 $8.82 \mathrm{Qt}-33.76 \mathrm{Qt}, \mathrm{CS} 3$ 은 $13.79-31.99 \mathrm{Qt}$ 으로 $\mathrm{CS} 2$ 에서 가 장 확대된 분포를 보인다. $\mathrm{CS} 2$ 의 Pitch span 분포는 한국어 $(9.90 \mathrm{Qt}-30.75 \mathrm{Qt})$ 와 모국어인 중국어(9.38Qt-39.10Qt) 사이에 위치해 있다.

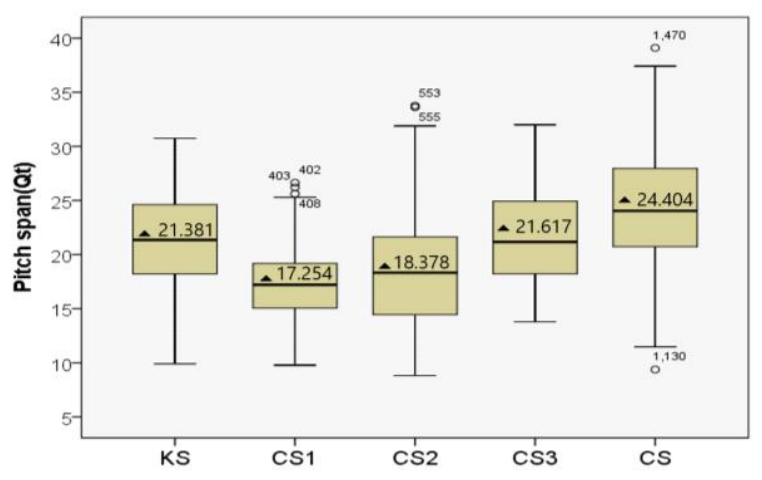

그림 3. 한국화자와 중국화자 발화문의 Pitch $\operatorname{span}(\mathbf{\Lambda}$ 평균값)

Figure 3. Pitch span of Korean sentences produced by $\mathrm{KS} \& \mathrm{CS}(\boldsymbol{\Delta}$ mean value $)$

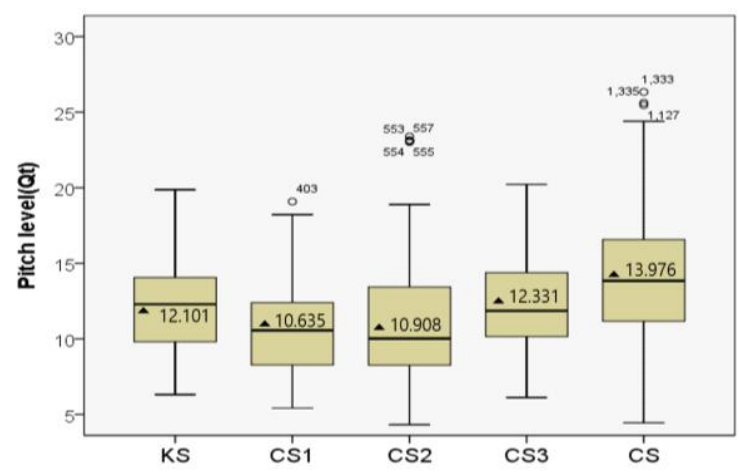

그림 4. 한국화자와 중국화자 발화문의 Pitch level(ㅍ평균값)

Figure 4. Pitch level of Korean sentences produced by $\mathrm{KS} \& \mathrm{CS}(\boldsymbol{\Delta}$ mean value $)$

그림 4의 Pitch level 값을 살펴보면 CS1은 평균 10.64Qt, CS2 는 $10.91 \mathrm{Qt}, \mathrm{CS} 3$ 은 $12.33 \mathrm{Qt}$ 이다. $\mathrm{CS} 1$ 의 평균값은 가장 낮으며 이는 한국어나 모국어인 중국어보다 $2 \mathrm{Qt}$ 이상 낮은 값이다. CS2 역시 CS1과 유사한 양상을 보인다. 반면 CS3의 경우, 평균값이 $\mathrm{KS}$ 의 $12.10 \mathrm{Qt}$ 보다 미세하게 높으나 모국어인 중국어의 $13.98 \mathrm{Q}$ 에는 훨씬 미치지 못하며 $\mathrm{KS}$ 에 근접해 있다. Pitch level의 분포 는 $\mathrm{CS} 1$ 이 5.42Qt-19.08Qt, $\mathrm{CS} 2$ 는 4.32Qt-23.39Qt, CS3은 6.12 $-20.22 \mathrm{Qt}$ 이다. Pitch level의 분포에서는 $\mathrm{CS} 1, \mathrm{CS} 2, \mathrm{CS} 3$ 모두 $\mathrm{KS}$ 보다 다소 확대된 양상을 보이는데 그 중 $\mathrm{CS} 2$ 의 분포가 가장 넓 으며 이는 한국어(6.31Qt-19.87Qt)보다 중국어(4.44Qt-26.33Qt) 의 Pitch level 분포에 가깝다.

이상에서 살펴본 Pitch span과 Pitch level값을 보면 초급 중국 인학습자에서는 음역 축소현상이 두드러지게 나타남을 알 수 있다. 즉 평균 Pitch span과 Pitch level값은 KS나 모국어인 CS보 다 낮은 음역대를 보이며 분포 양상에서도 $\mathrm{KS}$ 와 $\mathrm{CS}$ 보다 좁은 
대역에 집중되어 있다. 단 Pitch level의 분포에서는 $\mathrm{KS}$ 보다 미 세하게 확대되어 나타난다. 중급 역시 Pitch span과 Pitch level의 평균값이 $\mathrm{KS}$ 나 $\mathrm{CS}$ 보다 훨씬 낮은 음역대에 위치함으로써 초급 과 마찬가지로 음역 축소현상이 두드러지게 나타나고 있음을 알 수 있다. 그러나 Pitch span과 Pitch level의 분포에서는 KS의 범위를 벗어난 양상을 보이며 세 그룹 중 모국어인 중국어에 가 장 근접한 양상을 보인다. 이는 Pitch span 분포에서 최댓값이 $\mathrm{KS}$ 보다 높은 음역대에 이르고 있다는 것에서도 나타나는데 이 단계에서 어느 정도 모국어의 영향이 작용하는 것으로 조심스 럽게 볼 수 있을 것이다. 고급학습자는 Pitch span과 Pitch level의 평균값에서 $\mathrm{KS}$ 보다 미세하게 높게 나타나고 있다. 그러나 모국 어의 영향으로 보기에는 그 값이 $\mathrm{KS}$ 에 보다 근접해 있다. 따라 서 숙달도가 높은 $\mathrm{CS} 3$ 에서는 음역 축소현상이 약화되어 목표 어와 유사한 양상을 보인다고 할 수 있다. 또한 Pitch span의 분 포면에서도 그 변동 범위가 $\mathrm{KS}$ 와 가장 유사한 양상을 보인다.

따라서 Pitch span과 Pitch level값으로 본다면 숙달도가 낮을 수록 음역 축소현상이 두드러지게 나타나며 숙달도가 높아질 수록 축소현상이 완화되어 목표어와 유사한 모습을 보이고 있 다. 모국어 간섭현상은 두드러지게 나타나지 않으나 분포 면에 서 미약하게 관찰할 수 있는데 중급화자에게서 가장 잘 드러나 고 있다.

Pitch span과 Pitch level의 그룹 간 평균값이 통계적으로 유의 미한지 살펴보기 위해 일원배치 분산분석을 실시했다. 결과는 표2에 제시되었다.

표 2. Pitch span과 Pitch level의 일원배치 분산분석

Table 2. Results of one-way ANOVA on Pitch span and Pitch level

\begin{tabular}{|c|c|c|c|c|c|c|}
\hline & & $\mathrm{N}$ & Mean(SD) & $F$-value & $p$-value & 사후분석 \\
\hline \multirow{5}{*}{$\begin{array}{l}\text { Pitch } \\
\text { span }\end{array}$} & KS & 168 & $21.381(4.51)$ & \multirow{5}{*}{145.217} & \multirow{5}{*}{.000} & \multirow{5}{*}{$\begin{array}{c}\text { CS - } \\
\mathrm{KS} \cdot \mathrm{CS} 3- \\
\mathrm{CS} 1-\mathrm{CS} 2 *\end{array}$} \\
\hline & $\mathrm{CS} 1$ & 240 & $17.254(3.27)$ & & & \\
\hline & CS2 & 240 & $18.378(4.89)$ & & & \\
\hline & $\mathrm{CS} 3$ & 240 & $21.617(4.17)$ & & & \\
\hline & $\mathrm{CS}$ & 720 & $24.404(5.16)$ & & & \\
\hline \multirow{5}{*}{$\begin{array}{l}\text { Pitch } \\
\text { level }\end{array}$} & $\mathrm{KS}$ & 168 & $12.101(2.83)$ & \multirow{5}{*}{64.376} & \multirow{5}{*}{.000} & \multirow{5}{*}{$\begin{array}{c}\mathrm{CS}- \\
\mathrm{KS} \cdot \mathrm{CS} 3- \\
\mathrm{CS} 1 \cdot \mathrm{CS} 2^{*}\end{array}$} \\
\hline & $\mathrm{CS} 1$ & 240 & $10.635(2.83)$ & & & \\
\hline & $\mathrm{CS} 2$ & 240 & $10.908(3.70)$ & & & \\
\hline & CS3 & 240 & $12.331(2.81)$ & & & \\
\hline & $\mathrm{CS}$ & 720 & $13.976(3.82)$ & & & \\
\hline
\end{tabular}

A-B-C*: A, B, C, 그룹 간 유의미한 차이가 있음.

일원배치분산분석 결과 그룹 간 $\operatorname{Pitch} \operatorname{span}[F(4,1603)=145.217$, $p<.000]$ 과 Pitch level[ $F(4,1603)=64.376, p<.000]$ 에서 유의미한 차이가 발견되었다. 그러나 사후분석(Tukey HSD) 결과 Pitch $\mathrm{span}$ 에서는 $\mathrm{KS}$ 와 $\mathrm{CS} 3$ 간, $\mathrm{CS} 1$ 과 $\mathrm{CS} 2$ 간 그리고 Pitch level에서 는 $\mathrm{CS} 1$ 과 $\mathrm{CS} 2, \mathrm{KS}$ 와 $\mathrm{CS} 3$ 간에는 유의미한 차이가 나타나지 않 았다. 결과적으로 $\mathrm{KS}$ 와 가장 근접한 Pitch span과 Pitch level을 보인 $\mathrm{CS} 3$ 는 통계적으로도 $\mathrm{KS}$ 와 가장 유사함이 검증되었다.

\subsection{3. 집단 내 분석}

집단 내 분석은 초·중 - 고급 중국인 한국어 학습자들의 모 국어인 중국어 발화문(L1)과 목표어인 한국어 발화문(L2)에서
관찰된 Pitch span과 Pitch level의 비교 분석을 목표로 한다. 결과 는 그림 5(Pitch span)와 6(Pitch level)에 제시되었다.

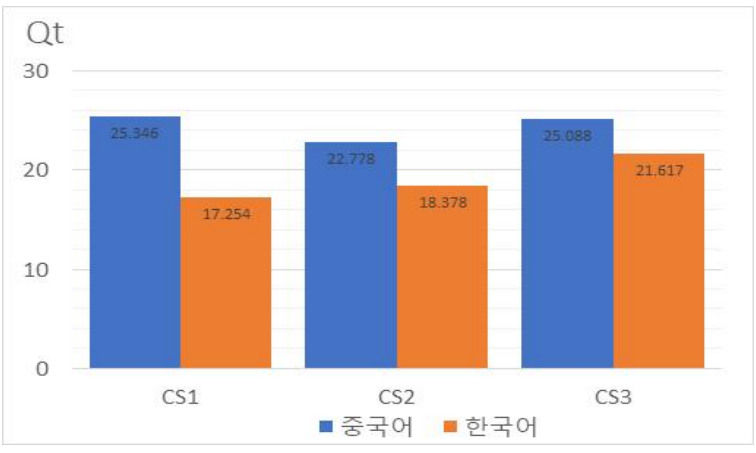

그림 5. 중국화자가 발화한 한국어와 중국어의 평균 Pitch span Figure 5. Mean Pitch span of Korean and Chinese sentences

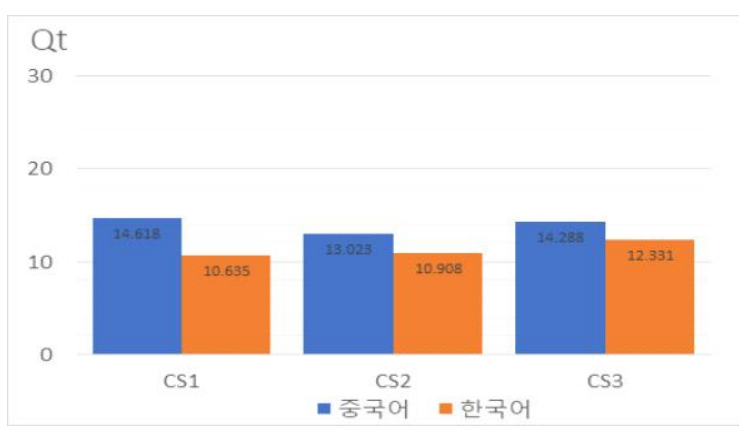

그림 6. 중국화자가 발화한 한국어와 중국어의 평균 Pitch level Figure 6. Mean Pitch level of Korean and Chinese sentences

우선 그림 5의 Pitch span을 살펴보면, 모든 그룹에서 한국어 발화문은 모국어인 중국어보다 축소되어 실현되었음을 알 수 있다. 그리고 축소 범위는 숙달도가 높아질수록 줄어듦도 알 수 있다. CS1의 한국어 발화문에서 Pitch span은 모국어인 중국어 보다 약 $8 \mathrm{Qt}$ 축소되었고 $\mathrm{CS} 2$ 는 $4 \mathrm{Qt}, \mathrm{CS} 3$ 는 $3.5 \mathrm{Qt}$ 축소되었다.

그림 6의 Pitch level에서도 동일한 양상을 관찰할 수 있다. 세 그룹 모두 한국어 발화문이 모국어보다 낮은 Pitch level을 보인 다. 그러나 숙달도가 높을수록 모국어와의 차이가 완화되고 있 음도 알 수 있다. CS1의 한국어 발화문에서 Pitch level은 모국어 인 중국어보다 약 $4 \mathrm{Qt}$ 이 축소되었고 $\mathrm{CS} 2$ 는 $2.1 \mathrm{Qt}, \mathrm{CS} 3$ 는 $1.9 \mathrm{Qt}$ 축소되어 실현되었다. 따라서 L2 학습자들은 목표어 발화에서 모국어와는 다른 축소된 피치 대역을 실현하고 있음을 확인할 수 있다. 숙달도가 높아질수록 모국어 음역대에 근접해지지만 그 범위가 목표어 화자들의 음역대를 크게 벗어나지 않는 범위 이다. 따라서 고급 화자들이 발화한 목표어 발화문에서의 피치 는 음역 축소현상에서 어느 정도 벗어나 목표어에 근접하고 있 음을 확인할 수 있다.

중국인 한국어 학습자들의 한국어(L2)와 중국어(L1)의 Pitch span과 Pitch level의 차이가 통계적으로 유의미한지 알아보기 위해 대응표본 $t$-검정을 실시했다. 결과는 표 3 에 제시되었다. 
표 3. 중국화자 발화문의 Pitch span과 Pitch level의 $t$-검정 Table 3. Results of $t$-test on Pitch span and Pitch level

\begin{tabular}{l|c|c|c|r|c}
\hline \multicolumn{2}{c|}{} & \multicolumn{2}{|c|}{ Mean(SD) } & \multirow{2}{*}{$t$-value } & \multirow{2}{*}{$p$-value } \\
\cline { 3 - 6 } \multicolumn{2}{c|}{} & 한국어 & 중국어 & & \\
\hline \multirow{2}{*}{ Pitch } & CS1 & $17.25(3.27)$ & $25.35(4.35)$ & -28.543 & .000 \\
\cline { 2 - 6 } span & CS2 & $18.38(4.89)$ & $22.78(5.42)$ & -8.897 & .000 \\
\cline { 2 - 6 } & CS3 & $21.62(4.17)$ & $25.09(5.26)$ & -8.703 & .000 \\
\hline \multirow{2}{*}{$\begin{array}{c}\text { Pitch } \\
\text { level }\end{array}$} & CS1 & $10.63(2.38)$ & $14.62(3.62)$ & -17.059 & .000 \\
\cline { 2 - 6 } & CS2 & $10.91(3.70)$ & $13.02(3.98)$ & -5.654 & .000 \\
\cline { 2 - 6 } & CS3 & $12.33(2.81)$ & $14.29(3.66)$ & -7.693 & .000 \\
\hline
\end{tabular}

통계분석 결과 Pitch span은 초급 $(t=-28.543, d f=239, p<.000)$, 중급 $(t=-8.897, d f=239, p<.000)$, 고급 $(t=-8.703, d f=239, p<.000)$ 의 모든 그룹에서 유의미한 차이가 나타났고, Pitch level 역시 초급 $(t=-17.059, d f=239, \quad p<.000), \quad$ 중급 $(t=-5.654, d f=239$, $p<.000)$, 고급 $(t=-7.693, d f=239, p<.000)$ 의 모든 그룹에서 유의 미한 차이가 관찰되었다.

\subsection{Pitch Dynamic Quotient(PDQ)}

$\mathrm{PDQ}$ 는 각 문장 내부에서의 음높이 변화 정도를 알아보기 위 해 측정되었다. 상기한 바와 같이 PDQ는 Zimmerer et al.(2014) 에서 사용된 방법으로 각 문장의 $\mathrm{F} 0$ 를 일정한 간격으로 측정한 후 그 평균의 표준편차를 평균값으로 나누어 구한다. PDQ는 F0 값을 정량화하고 집단 간 차이를 최소화하면서 언어 간 비교를 더 용이하게 한다고 한다. 본 연구에서는 음역 축소현상과 모국 어 간섭현상을 언어 간 그리고 그룹 간 비교하기 위하여 각 문 장의 $\mathrm{PDQ}$ 값을 측정하였다. $\mathrm{PDQ}$ 값을 산출하기 위해 우선 각 문 장의 F0 값을 Praat의 'pitch listing' 기능을 사용하여 $0.15 \mathrm{~ms}$ 간 격으로 측정하였고 측정된 값으로부터 각 문장의 평균과 표준 편차를 구한 후 표준편차를 평균값으로 나누어 산출하였다. 결 과는 그림 7에 언어별 그리고 그룹별로 제시되었다.

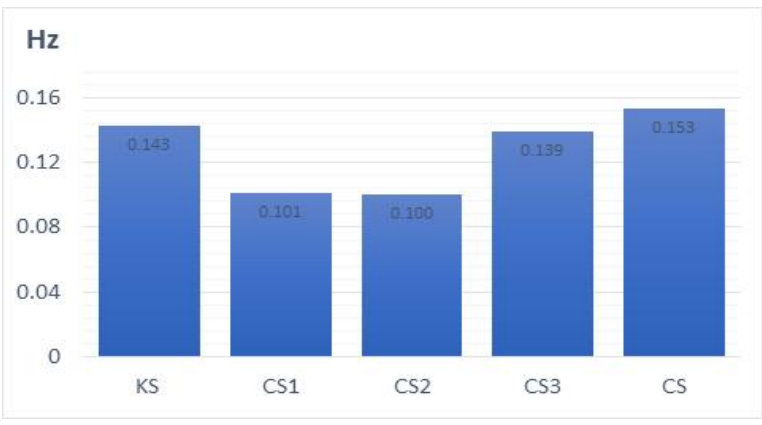

그림 7. 한국어와 중국어 문장의 평균 $\mathrm{PDQ}$

Figure 7. Mean PDQ of Korean and Chinese sentences

결과를 살펴보면 $\mathrm{PDQ}$ 값은 중국어(CS)가 0.153으로 가장 높 고 $\mathrm{KS}$ 가 0.143, CS1이 0.101, CS2가 0.100 그리고 $\mathrm{CS} 3$ 가 0.139로 나타났다. 우선 언어 간 차이를 살펴보면 중국어는 한국어보다 상대적으로 높은 PDQ 값을 가지므로 문장 내 음높이 변동이 한 국어보다 심하다고 할 수 있다. 모국어의 간섭이 나타난다면 $\mathrm{CS} 1$ 과 $\mathrm{CS} 2, \mathrm{CS} 3$ 의 발화문의 $\mathrm{PDQ}$ 는 중국어에 근접해 나타날 것 이다. 그러나 $\mathrm{CS} 1$ 과 $\mathrm{CS} 2$ 는 한국어와 중국어 모두에서 멀어진
낮은 $\mathrm{PDQ}$ 수치를 보이고 있다. 즉 이 두 그룹의 문장 내 음높이 는 목표어인 한국어나 모국어인 중국어보다 단조로운 변화를 보인다고 할 수 있다. 게다가 숙달도가 높은 CS2의 PDQ가 CS1 보다 미세하게 낮게 나타나고 있다. 이는 Pitch span과 Pitch level 에서는 $\mathrm{CS} 2$ 가 $\mathrm{CS} 1$ 보다 넓은 음역대에 걸쳐 실현되나 문장 내부 에서의 음높이 변화는 두 그룹이 유사하게 나타나는 것으로 볼 수 있다. 반면 $\mathrm{CS} 3$ 은 이들보다 높은 $\mathrm{PDQ}$ 수치를 보인다. 목표 어나 모국어인 중국어보다 낮으나 목표어에 훨씬 근접한 수치 이다. 즉 $\mathrm{CS} 3$ 의 문장 내 음역 변동이 $\mathrm{KS}$ 와 가장 유사함을 알 수 있다. 따라서 문장 층위의 음역 변동에서도 모국어 간섭이 두드 러지게 작용하는 것은 아님을 알 수 있으며 전반적으로 음역 축 소현상이 우세하게 나타남을 알 수 있다.

언어 간 그리고 그룹 간 $\mathrm{PDQ}$ 의 차이가 통계적으로 유의미한 지 알아보기 위해 일원배치 분산분석을 실시했다. 결과는 표 4 에 제시되었다.

표 4. $\mathrm{PDQ}$ 값에 대한 일원배치 분산분석 Table 4. Results of one-way ANOVA on PDQ

\begin{tabular}{|c|c|c|c|c|c|}
\hline & $\mathrm{N}$ & Mean(SD) & $F$-value & $p$-value & 사후분석 \\
\hline $\mathrm{KS}$ & 168 & $.143(.035)$ & \multirow{5}{*}{79.340} & \multirow{5}{*}{.000 } & \multirow{5}{*}{$\begin{array}{c}\mathrm{CS}- \\
\mathrm{CS} 3 \cdot \mathrm{KS}- \\
\mathrm{CS} 1 \cdot \mathrm{CS} 2^{*}\end{array}$} \\
\hline $\mathrm{CS} 1$ & 240 & $.101(.021)$ & & & \\
\hline $\mathrm{CS} 2$ & 240 & $.100(.032)$ & & & \\
\hline CS3 & 240 & $.139(.038)$ & & & \\
\hline $\mathrm{CS}$ & 720 & $.153(.067)$ & & & \\
\hline
\end{tabular}

A-B-C ${ }^{*}, \mathrm{~A}, \mathrm{~B}, \mathrm{C}$ 세 그룹 간 유의미한 차이가 있음.

통계분석 결과 $\mathrm{PDQ}$ 는 언어 간 그리고 그룹 간 유의미한 차이 가 나타났다 $[F(4,1603)=79.340, p<.000]$. 그러나 사후분석 결과 $\mathrm{CS} 1 \cdot \mathrm{CS} 2, \mathrm{KS} \cdot \mathrm{CS} 3$ 간에는 유의미한 차이가 나타나지 않았다. $\mathrm{PDQ}$ 수치에서도 $\mathrm{CS} 3$ 는 통계적으로 $\mathrm{KS}$ 와 가장 유사함이 검증 되었다고 할 수 있다.

\section{3. 왜도와 첨도}

언어 간 그리고 집단 간 음높이 분포 양상을 비교하기 위해 왜도와 첨도 값을 측정하였다. 상기한 바와 같이 이 두 변수는 분석자료의 정규성과 언어 간 또는 집단 간 음높이 자료의 분포 양상을 비교할 수 있게 한다. 왜도와 첨도 분석에 사용된 자료 는 화자의 전체적인 음역대의 변화 양상을 살펴볼 수 있는 Pitch span 값을 사용하였다. 그러나 보다 세부적인 음높이 분포 양상 을 살피고자 각 문장의 $\mathrm{F} 0$ 값을 $0.15 \mathrm{~ms}$ 마다 측정하여 단락 최 솟값과의 차이를 구한 후 $1 / 4$ tone으로 변환한 Pitch span 값을 사 용하였다. 결과는 표 5 에 제시되었다.

표 5. Pitch span 값의 왜도와 첨도

Table 5. Skewness and kurtosis of Pitch span

\begin{tabular}{c|c|c|c|c|c|c}
\hline \multicolumn{2}{c|}{} & KS & \multicolumn{1}{c|}{ CS1 } & CS2 & CS3 & \multicolumn{1}{c}{ CS } \\
\hline \multirow{2}{*}{$\begin{array}{c}\text { Pitch } \\
\text { span }\end{array}$} & 왜도 & .465 & .162 & .462 & .505 & .364 \\
\cline { 2 - 7 } & 첨도 & -.131 & -.544 & -.251 & -.204 & -.343 \\
\hline
\end{tabular}

표 5의 결과를 살펴보면 모든 자료는 왜도와 첨도 값이 기본 값인 0에 가까우므로 정규분포에서 크게 벗어나지 않고 있음을 
알 수 있다. $\mathrm{KS}$ 의 왜도값은 0.465 로 중국어의 0.364 보다 상대적 으로 크다. 이는 $\mathrm{KS}$ 의 Pitch span 값의 자료가 $\mathrm{CS}$ 에 비해 상대적 으로 왼쪽, 즉 낮은 값에 집중되어 있음을 나타낸다. 따라서 모 국어 첨도값보다 커진 $\mathrm{CS} 2$ 와 $\mathrm{CS} 3$ 의 데이터가 $\mathrm{KS}$ 와 유사하며 $\mathrm{CS} 1$ 은 $\mathrm{CS}$ 와 $\mathrm{KS}$ 에서 멀어져 정규분포에 더 가깝다고 할 수 있 다. 첨도 값의 경우 모든 그룹에서 음의 값을 가지므로 정규분 포보다는 데이터가 중심에 덜 몰려 있음을 알 수 있다. 그리고 절대값이 가장 작은 한국어가 중국어보다 상대적으로 중앙 집 중도가 높음을 알 수 있다. 중국인학습자들의 경우, $\mathrm{CS} 3$ 의 첨도 값이 $\mathrm{KS}$ 에 가장 근접해 있으며 절대값이 가장 큰 $\mathrm{CS} 1$ 의 값은 $\mathrm{KS}$ 와 $\mathrm{CS}$ 로부터 가장 멀어져 데이터의 중앙 집중도가 가장 약 한 것으로 나타난다.

왜도와 첨도 값을 통해 한국어와 중국어의 자료분포에 상대 적 차이가 있음을 알 수 있다. 그리고 숙달도가 높은 CS3의 자 료는 $\mathrm{CS}$ 보다는 $\mathrm{KS}$ 에 근접한 분포를 보이며 숙달도가 낮은 $\mathrm{CS} 1$ 은 $\mathrm{KS}$ 와 $\mathrm{CS}$ 모두와 다른 분포를 보임을 알 수 있다. 따라서 자 료의 분포 면에서 특별한 모국어 간섭현상은 관찰되지 않았다.

\section{4. 의미와 피치}

선행연구(Zimmerer et al., 2014)에서는 문장의 의미 인지 여부 가 음역 사용에 영향을 미칠 수 있음을 시사하고 있다. 화자가 발화문의 의미를 모르는 경우, 분절음이나 단어 발음에 더 집중 하게 되기에 목표어 화자와 유사한 음역 실현을 방해하는 축소 현상이 나타날 수 있다는 것이다. 이는 담화의 전체 의미를 알 고 있는 경우 개별 단어에 집중하지 않아도 되므로 전체적인 음 역 사용이 훨씬 자유로울 것임을 의미하기도 한다. 이런 맥락에 서 본다면 본 연구의 분석자료에서 난이도가 가장 낮은 Text(1) 의 음역 변화가 가장 활발히 나타날 것이며 그보다 난이도가 높 은 Text에서는 음역 변동이 상대적으로 제한적일 것으로 가정 할 수 있다. 그리고 의미 인지 여부와 음역 간 상관성이 나타난 다면 음역 축소현상은 이 상관성에 의해 설명될 수 있을 것이다.

중국인 학습자들의 한국어 발화문의 의미 인지 여부, 즉 난이 도와 음역 변동 간의 관계는 Pitch span과 PDQ 값을 통해 살펴보 았다. 결과는 그림 8과 9에 제시되었다.

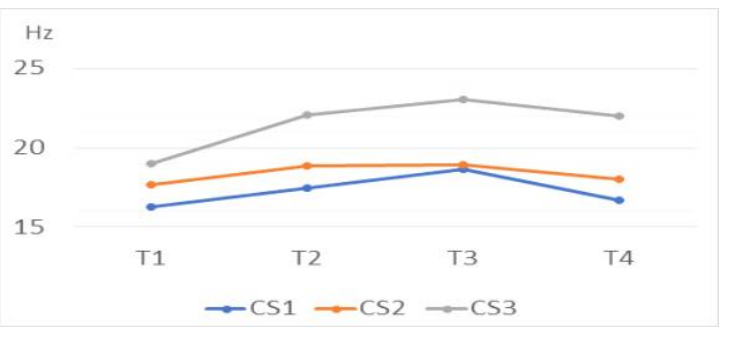

그림 8. 텍스트 난이도에 따른 평균 Pitch span Figure 8. Mean Pitch span according to text difficulty

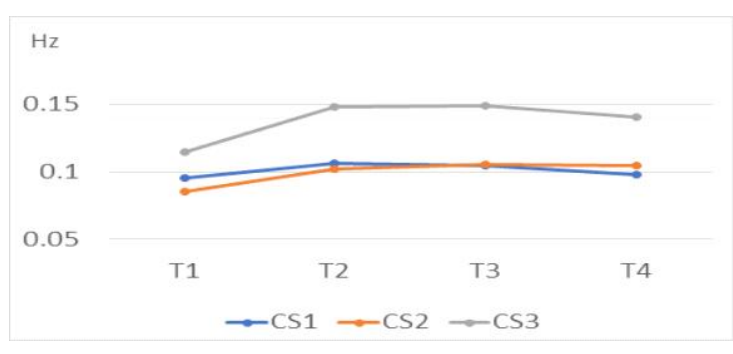

그림 9. 텍스트 난이도에 따른 평균 $\mathrm{PDQ}$

Figure 9. Mean PDQ according to text difficulty

우선 그림 8에서 각 집단별로 Text(1)-(4)의 평균 Pitch span 값을 살펴보면 $\mathrm{CS} 1$ 은 $16.32 \mathrm{Qt}, 17.45 \mathrm{Qt}, 18.68 \mathrm{Qt}, 16.71 \mathrm{Qt}$ 이며, $\mathrm{CS} 2$ 는 $17.67 \mathrm{Qt}, 18.87 \mathrm{Qt}, 18.92 \mathrm{Qt}, 18.01 \mathrm{Qt}$, 그리고 $\mathrm{CS} 3$ 은 19.01Qt, 22.06Qt, 23.05Qt, 22.01Qt으로 나타났다. 난이도 증가 에 따른 특별한 음역 축소현상은 나타나지 않고 있다.

그림 9의 $\mathrm{PDQ}$ 값도 유사한 양상으로 나타난다. CS1은 각 text 별로 $0.0957,0.1064,0.1048,0.0984$ 이며 CS2는 0.0858, 0.1022, $0.1053,0.1048$, 그리고 $\mathrm{CS} 3$ 은 $0.11500 .1484,0.1491,0.1403$ 의 분 포를 보인다. 따라서 $\mathrm{PDQ}$ 값에서도 텍스트의 난이도와 음높이 변동 간 상관성은 드러나지 않고 있다. 오히려 난이도가 높아 학습자들이 의미를 파악하기 힘들 것으로 예상된 담화의 음높 이가 확대되어 실현되고 있다. 이는 담화의 이해도 또는 난이도 가 음역에 영향을 주는 주된 요인이 아닐 수 있음을 시사한다. 따라서 본 연구에서 나타나는 텍스트 간 음역 차이를 설명하기 위해서는 텍스트 구성 요소들 즉 어휘의 성질(고유어 단어와 한 자어 단어)과 분절음 특징, 문장의 통사구조와 초점구조 등에 대한 보다 면밀한 분석이 필요해 보인다.

각 텍스트별 Pitch span 값과 PDQ 값이 통계적으로 유의미한 지 살펴보고자 일원배치 분산분석을 실시했다. 결과는 표 6 에 제시되었다.

표 6. 텍스트 난이도에 대한 일원배치 분산분석

Table 6. Results of one-way ANOVA on text difficulty

\begin{tabular}{|c|c|c|c|c|c|c|c|c|}
\hline & & \multicolumn{4}{|c|}{ Mean } & \multirow{2}{*}{\multicolumn{2}{|c|}{$F$-value $p$-value }} & \multirow{3}{*}{\begin{tabular}{|c|} 
사후분석 \\
T1-T3 ${ }^{*}, \mathrm{~T} 3-\mathrm{T} 4{ }^{*}$ \\
\end{tabular}} \\
\hline & & $\mathrm{T} 1$ & $\mathrm{~T} 2$ & T3 & $\mathrm{T} 4$ & & & \\
\hline \multirow{3}{*}{$\begin{array}{c}\text { Pitch } \\
\text { span }\end{array}$} & 초급 & 16.32 & 17.45 & 18.67 & 16.71 & 5.550 & .001 & \\
\hline & 중급 & 17.67 & \begin{tabular}{|l|}
18.87 \\
\end{tabular} & 18.92 & 18.01 & .919 & .423 & - \\
\hline & 고급 & 19.01 & 22.06 & 23.05 & 22.01 & 9.953 & .000 & $\begin{array}{l}\mathrm{T} 1-\mathrm{T} 2 \cdot \\
\mathrm{T} 3 \cdot \mathrm{T} 4\end{array}$ \\
\hline \multirow{3}{*}{$\begin{array}{l}\text { Pitch } \\
\text { level }\end{array}$} & 초급 & .0957 & 1064 & .1048 & .0984 & 3.534 & .016 & $\mathrm{~T} 1-\mathrm{T} 2^{*}$ \\
\hline & 중급 & .0858 & 1022 & .1053 & .1048 & 4.401 & .005 & $\begin{array}{l}\mathrm{T} 1-\mathrm{T} 2 \cdot \\
\mathrm{T} 3 \cdot \mathrm{T} 4\end{array}$ \\
\hline & 고급 & .1150 & .1484 & .1491 & .1403 & 10.024 & .000 & $\begin{array}{l}\mathrm{T} 1-\mathrm{T} 2 \cdot \\
\mathrm{T} 3 \cdot \mathrm{T} 4\end{array}$ \\
\hline
\end{tabular}

Pitch span의 경우, 중급 $[F(3,236)=.919, p=.432]$ 을 제외한 초 급 $[F(3,236)=5.550, p<.001]$ 과 고급 $[F(3,236)=9.953, p<.000]$ 에 서 텍스트에 따른 음높이 차이가 유의미한 것으로 나타났다. $\mathrm{PDQ}$ 는 초급 $[F(3,236)=3,534, p=.016]$, 중급 $[F(3,236)=4.401$, $p=.005]$, 고급[ $F(3,236)=10.024, p<.000]$ 의 모든 그룹에서 유의 미한 차이가 발견되었다. 그러나 상기한 바와 같이 난이도가 낮 
은 텍스트의 피치가 확대될 것이라는 가설은 검정 되지 않았다. 따라서 숙달도가 낮은 단계에서 나타난 음역 축소현상이 단지 발화문의 이해 여부에 의해 설명 되어질 수 없음을 알 수 있다.

\section{5. 결론}

본 연구는 제 2 언어 습득과정에서 나타나는 언어 보편적 간 섭현상인 음역 축소현상과 언어 특수적 현상인 모국어 간섭현 상이 어떤 양상으로 충돌 또는 상호작용하는지 중국인 한국어 학습자들의 한국어 발화문을 중심으로 살펴보았다. 한국어와 중국어는 언어유형론적으로 다르며 이러한 대조언어학적 이론 을 바탕으로 두 요인의 상호작용 양상을 조사하고자 언어 간 분 석, 집단 간 분석, 집단 내 분석을 실시하였다. 음성분석 변수로 는 Pitch span 및 Pitch level, PDQ, 그리고 왜도 및 첨도가 사용되 었다. 이 변수들은 각각 음역의 전반적 변동 폭, 각 문장 내 음높 이의 변화량, 그리고 분석자료의 분포 양상을 조사하고자 사용 되었다. 이와 더불어 텍스트 난이도와 음높이 간 관련성도 분석 되었다.

언어 간 분석 결과, 중국어는 한국어에 비해 확대된 음역과 높은 문장 음높이로 생성되었다. 이를 통해 중국인 학습자들의 한국어 발화문에 모국어 간섭이 나타난다면 상대적으로 확대 된 음역과 문장 음높이의 상승을 관찰할 수 있을 것으로 예측되 었다. 그러나 집단 간 비교 결과, 숙달도가 낮을수록 음역이 좁 아지고 문장의 평균 음높이도 낮아지는 피치 축소현상이 지배 적으로 나타났다. 그리고 숙달도가 높은 고급 학습자에서는 음 역 축소현상이 완화되어 목표어 음높이와 유사하게 실현되었 다. 그러나 뚜렷한 모국어 간섭현상은 발견되지 않았다. 이러한 결과는 집단 내 분석 즉 중국인 학습자의 모국어인 중국어와 목 표어인 한국어 음높이 비교에서도 관찰되었다. 숙달도가 높을 수록 모국어와의 편차가 줄어들었으나 축소 범위가 목표어 화 자들의 음역대를 크게 벗어나지 않기에 모국어 간섭으로 보기 에는 무리가 있었다. 또한 이러한 양상은 본 연구에서 분석된 Pitch span과 Pitch level, PDQ, 왜도와 첨도 등 모든 변수에서 유 사하게 관찰되었다. 단 중급 학습자들의 경우 Pitch span과 Pitch level의 분포에서 최댓값이 목표어 화자들의 음역 범위를 벗어 나 모국어인 중국어에 근접한 분포를 보였는데 이는 모국어의 영향이 부분적으로 작용할 수 있음을 나타내는 것으로 판단되 었다.

따라서 본 연구를 통해 선행연구에서 보고된 L2 억양의 음역 축소현상을 확인할 수 있었다. 특히 숙달도가 낮은 단계에서는 모국어 간섭보다 음역 축소현상이 우세하게 작용하는 것으로 나타났다. 그리고 중급학습자들의 결과에서 볼 수 있듯이 일부 단계에서는 미약하게나마 음역 축소와 모국어 간섭이 동시에 나타날 가능성도 배제할 수는 없다. 이런 의미에서 본다면 중급 단계는 음역 축소나 모국어간섭 중 하나가 가장 활발하게 나타 나는 단계가 아니라 두 현상이 공존하는 단계일 수 있다. 그리 고 고급 단계에서는 음역 축소현상이 완화되어 목표어에 가장 근접한 음역대를 보여줌을 확인할 수 있었다. 이와 더불어 숙달
도가 낮은 단계에서 나타나는 음역 축소현상이 단지 발화문의 이 해도나 난이도에 의해 설명 되어질 수 없음도 관찰할 수 있었다.

그러나 본 연구는 음운론적 층위가 아닌 음성학적 층위에서 실시되었다. 따라서 상기된 결과 또한 음성학적 층위의 특징으 로 귀속된다. 음운론적 층위에서의 음높이 특징은 또 다른 양상 으로 나타날 수 있다. 즉 음성학적 층위에서 음역 축소현상이 우세하게 나타난다면 음운론적 층위에서는 모국어 간섭현상이 활발히 나타날 수 있다. 따라서 음역 축소현상과 모국어 간섭 현상 간 보다 정확한 상호작용을 살피기 위해서는 음운론적 분 석이 병행되어야 할 것으로 보인다.

그 외에도 본 연구는 제한된 분석자료와 피험자를 대상으로 실시되었고 음성 변수 간 상호작용이 다각적으로 분석되지 못 했다는 한계도 있다. 따라서 본 연구의 결과를 일반화하기에는 무리가 있다. 이러한 한계는 후속 연구를 통해 보완하고자 한다.

\section{References}

Andreeva, B., Demenko, G., Wolska, M., Möbius, B., Zimmerer, F., Jügler, J., Oleskowicz-Popiel, M., ... Trouvain, J. (2014, January). Comparison of pitch range and pitch variation in Slavic and Germanic Languages. Proceedings of the 7th Prosody Conference (pp. 776-780). Dublin, Ireland.

Bartkova, K., Bonneau, A., Colotte, V., \& Dargnat, M. (2012). Production of "continuation contours" by French speakers in L1(French) and L2(English). Retrieved from https:/www. researchgate.net/publication/266344815_Productions_of_continu ation_contours_by_French_speakers_in_L1_French_and_L2_En glish

Busà, M. G. (2010). Effects of L1 on L2 pronunciation: Italian prosody in English. In A. Maley, \& C. Gagliardi (Eds.), EIL, ELF, global English: Teaching and learning issues (pp. 207-228). Bern, Switzerland: Peter Lang.

Graham, C., \& Post, B. (2018). Second language acquisition of intonation: Peak alignment in American English. Journal of Phonetics, 66, 1-14.

Hosseini, A. (2013). L1 interference in L2 prosody: Contrastive focus in Japanese and Persian. Journal of Logic Language and Information, $11,55-67$.

Jun, S. A. (2000). K-ToBI (Korean ToBI) labelling conventions. Retrieved from https://linguistics.ucla.edu/people/jun/ktobi/ktobi 3-2.pdf

Jun, S. A., \& Oh, M. (2000, October). Acquisition of second language intonation. 6th International Conference on Spoken Language Processing, ICSLP 2000 (Inter-speech 2000) (pp. 73-76). Beijing, China.

Jung, H. (2014). The influence of Chinese neutral tone on boundary tone of Korean. (Master's thesis). Hankuk University of Foreign Studies, Seoul, Korea. 
Ladd, D. R. (1996). Intonational phonology. Cambridge, UK: Cambridge University Press.

Katarina, B., Bonneau, A., Colotte, V., \& Dargnat, M. (2012). Productions of "continuation contours" by French speakers in L1 (French) and L2 (English). Retrieved from https://www. researchgate.net/publication/266344815_Productions_of_continuation_c ontours_by_French_speakers_in_L1_French_and_L2_English

Kim, T. K., \& Baek, G. M. (2016). Accentual phrase realization in second language acquisition: The case of Korean-learning Chinese. The Korean Language and Literature, 68, 93-114.

Lee, M., \& Sohn, N. (2010). Tonal pitch variation of spontaneous speech in standard Chinese. Journal of Chinese Language and Literature, 55, 373-398.

Mennen, I. (2004). Bi-directional interference in the intonation of Dutch speakers of Greek. Journal of Phonetics, 32(4), 543-563.

Mennen, I. (2007). Phonological and phonetic influences in non-native intonation. In J. Trouvain, \& U. Gut (Eds.), Non-native prosody: Phonetic description and teaching practice (pp. 53-76). Boston, MA: De Gruyter Mouton.

Mennen, I., Schaeffler, F., Dickie, C. (2014). Second language acquisition of pitch range in German learners of English. Studies in Second Language Acquisition, 36(2), 303-329.

Park, J. (2009). A study of Korean utterances of Chinese Korean learners: Regarding dialogic intonation (Master's thesis). Ewha Womans University, Seoul, Korea.

Park, J. (2012). A comparative study of Korean intonation produced by Korean speakers and Chinese speakers (Master's thesis). Hanyang University, Seoul, Korea.

Ueyama, M. (1997, September). The phonology and phonetics of second language intonation: The case of "Japanese English". Proceedings of the Fifth European Conference on Speech Communication and Technology (pp. 2411-2414).

Ullakonoja, R. (2007, August). Comparison of pitch range in Finnish (L1) and Russian (L2). Proceedings of the ICPhS XVI (pp. 1701-1704). Saarbrücken, Germany.

Yuan, J., \& Liberman, M. (2014). F0 declination in English and Mandarin broadcast news speech. Speech Communication, 65, 67-74.

Zimmerer, F., Jügler, J., Andreeva, B., Möbius, B., \& Trouvain, J. (2014, May). Too cautious to vary more? A comparison of pitch variation in native and non-native productions of French and German speakers. Proceedings of the Speech Prosody 2014 (pp. 1037-1041). Dublin, Ireland.

- 윤영숙 (Youngsook Yune) 교신저자 경남대학교 교양융합대학 교수 경남 창원시 마산합포구 경남대학로 7
Tel: 055-249-6322

Email: ysy@kyungnam.ac.kr

관심분야: 음성학, 음운론, 인지 언어학 
한국어 분석자료

(1) 나는 요리하는 것을 좋아한다. 그래서 우리 집에서는 내가 요리를 한다. 우리나라 음식도 잘하고 다른 나라 음식도 잘한다. 매일 요리를 해서 부모님과 같이 먹는다. 부모님 이 내가 만든 음식을 맛있게 드시는 모습을 보면 기분이 좋다.

(2) 기숙사는 학교에서 아주 가까운 거리에 있다. 외관은 노후 하고 허름해 보인다. 그러나 내부는 매우 세련되고 현대적 이다. 여러 편의시설도 구비되어 있다. 공부로 지친 머리 를 식힐 수 있는 아늑한 공간들도 많다. 기숙사가 가파른 산비탈에 위치해 친구들은 다니기 힘들다고 한다. 하지만 나는 그마저도 마음에 든다.

(3) 새로운 아이디어를 만들어 내는 것은 힘든 일이다. 그러나 따지고 보면 새로운 것도 이미 존재하는 것의 또 다른 조 합이다. 이 사실만 기억하면 새로운 것을 만드는 것도 쉬 워진다. 따라서 어떤 것을 만들 때에는 그것과 유사한 것 들을 모사한다. 그다음에 자신만의 시각으로 변화를 주면 된다.

(4) 말은 언어 그 이상이다. 그것은 한 사람이 자라가는 과정 이다. 그리고 세계와 이어지는 방식이다. 말 그릇이 큰 사 람은 자신의 품만큼 말을 채운다. 말을 담는 그릇이 크기 에 자리도 넉넉하다. 다른 사람의 말을 끝까지 듣고 받아 들인다. 그리고 받은 말이 쉽게 새나가지 않는다.
중국어 번역본 분석자료

(1) 我喜欢做饭。所以在我们家我做饭。我们国家的饭荣做得 很好，其他国家的也很擅长。每天做饭和父母一起吃。看 到父母津津有味地吃我做的饭荣, 心情很好。

(2) 宿舍在距离学校很近的地方。外观陈旧简陃。但是内部简 洁且现代化。具备各种便利设施。有很多舒适的空间可以 使你忘却学习带来的烦恼。宿舍位于陡峭的山坡上, 朋友 们都说来回很累。尽管如此我还是很喜欢。

(3) 想出新的创意是件困难的事。但仔细分析，创新也只是将 现存的想法组合。只要记住这个事实，创新就会变得很容 易。因此，在创造某种东西时可先模仿与其类似的东西。 然后用自己的想法进行改变即可。

(4) 言语在语言之上。它是一个人成长的过程。也是与世界相 连的方式。高语境之人在表达上含蓄而内敛。因为语境高 所以也善于理解。吸收且接受别人所讲的话。并且不轻易 泄露所听之言。 


\title{
$\mathrm{L} 2$ 억양에서 나타나는 모국어 간섭과 언어 보편적 간섭현상의 상호작용: 피치대역을 중심으로*
}

\author{
윤 영 숙
}

경남대학교 교양융합대학

\section{국문초록}

본 연구는 제 2 언어 억양습득 과정에서 나타나는 언어 보편적 간섭현상인 피치대역(음역) 축소현상과 모국어 간섭 현상이 어떤 양상으로 상호작용하며 한국어 습득과정에서 어떤 순서로 나타나는지 중국인 한국어 학습자들을 통 해 살펴보았다. 본 연구에는 7 명의 한국어 원어민 화자와 초·중· 고급 수준의 중국인 한국어 학습자 각 10 명 총 37 명이 발화 실험에 참여하였다. 연구 참여자들은 난이도가 다른 한국어 담화 4 개와 이를 중국어로 번역한 중국어 담화 4개를 낭독 발화하였다. 한국어화자와 중국인 학습자들이 산출한 음성자료는 음성분석 프로그램 Praat을 사 용하여 각 문장별로 Pitch span, Pitch level, Pitch dynamic quotient(PDQ), 왜도와 첨도를 측정하였고 이후 언어 간 분 석, 그룹 간 분석, 그룹 내 분석을 통해 두 현상의 상호작용양상을 살펴보았다. 언어 간 분석결과 중국어는 한국어 보다 높은 Pitch span과 Pitch level로 특징지어졌다. 이를 바탕으로 초 - 중 - 고급 중국인 학습자들의 한국어 발화문 에 대한 그룹 간 분석을 실시하였다. 그 결과 초급과 중급 학습자들에게서는 모국어 간섭보다는 음역 축소현상이 두드러지게 나타났으며 고급 학습자들은 음역 축소현상이 완화되어 한국 화자에 근접한 양상을 보여주었다. 중국 인 학습자들이 발화한 목표어인 한국어와 모국어인 중국어 문장을 대상으로 한 그룹 내 분석에서도 숙달도가 높을 수록 모국어와 목표어 간 피치 편차가 줄어들어 음역 축소현상이 완화되었다. 문장 내 피치 변동 범위를 파악하기 위한 $\mathrm{PDQ}$ 분석에서 중국어 문장은 한국어 문장보다 음역 변동범위가 크다는 것을 알 수 있었다. 그룹 간 분석에서 는 초 - 중급 학습자들의 $\mathrm{PDQ}$ 가 한국어와 중국어보다 현저히 낮은 값을 보였다. 고급학습자들도 한국어나 중국어 보다 낮은 수치를 보였으나 한국어에 근접한 양상으로 나타났다. 이상의 결과를 바탕으로 숙달도가 낮은 화자일수 록 음역 축소 현상이 두드러지게 나타나며 고급 화자의 경우 목표어인 한국어와 유사한 양상으로 실현됨을 알 수 있었다. 따라서 본 연구의 분석 대상인 음성학적 층위에서는 모국어 간섭현상이 뚜렷하게 관찰되지 않았다.

핵심어: 2언어 억양, 피치 대역, 피치 편차, 음역 축소 현상, 모국어간섭현상

\section{참고문헌}

김태경, 백미경. (2016). 중국인 학습자의 한국어 습득과정에서 나타난 강세구 실현 양상 연구. 우리말글, 68, 93-114.

박지연. (2009). 중국어권 학습자의 한국어 억양 실현 양상 연구. 대화체 문장을 대상으로. 이화여자대학교 석사학위논문.

박지현. (2012). 중국인 학습자와 한국인의 억양비교연구. 한양대 학교 석사학위논문.

이미경·손남호 (2010). 중국어 자연 발화의 성조 음높이 변화. 중 국어문학, 55, 373-398.
정혜인 (2014). 중국어 경성이 한국어 문말 억양에 미치는 영향․․ 한국외국어대학교 석사학위논문.

* 이 논문은 2020년 대한민국 교육부와 한국연구재단 인문분야 중견연구자지원사업의 지원을 받아 수행된 연구임(NRF-2020S1A5A2A01044515). 